uterus only lecently evacuated. In the fundus of the uterus, it was now my extreme good fortune to find adherent an irregular lacerated pateh of chorionie membrane, about four inches long and an inch broad. It was tound to be f'etid. After this, I left the patient. Botl pulse amd temperature fell in a marked manuer after this operation. The alamning appearance and symptoms disapleared. 'Ihe pulse reminied liogh for several days; but the extreme anxiety of the physician and firiends was sublurd for good. The fetor of the diseharge was recognized by the nurse after ny visit, lont only at first, or for less than a day.

While, as is well known, there is often insuperable diflienlty in classifying cases of so-called purrperal fever under the heads pyamia, septicamia, ichoramia, there can in this instance be no hesitation in designating the disease as simple septicania. Snch cases are fimiliar to the gynecolongist. A deconposing uterine fibroid, a decomposing blood-clot in a hamatocele, produce sliverings, sweatings, vomiting, delirimn, high pulse, higl temperature: a most alarming combination of symptoms, which, ou the removal of their cause, is dissipated with extraondnary rapidity, in a few hours, as if by a elitrm. Such was the fortunate course of events in the case just marrated ; but, lad the putrefying membrane continued much longer in a puerperal uterus, a fatal result was probable.

In the case which I have narrated, the greatest care and attention did not secure the complete withdraral of the menbranes. "The position of the persistently romaining shred rencless it unlikely that any forecps would have reached it and renover it entirely; nor is it probable that it would have come away in the discharges early chough to allow of the preservation of life, alrealy most serionsly threateued. It is uncler these circumstinces that 1 propose the new operation of investigating the interior of the nterus by the carefilly carbolized hand of tle accoucheur, with a view to finling and removing decomposing sulstance. In such a state of matters, I have hitherto used the practice of baudelocque; namely, antiseptie intra-uterine injections. I employ a double catheter, and I lave repeatedly liad reason to be satistied with the results. But, in the eases wlicie I have used this treatment suceessfully, there has not been washed out by the injections any shred of lidden membrane; and I very much donbt whether injections in the cuse which I have narrated, would have prorluced this supreme result; for; besides the difficulty of directing the current so as to envelop and remove the adherent membrane, there is the absence of any knowledge where the lidden membrane is-absence, perhaps, cren of suspicion of its presence.

There is, of course, as yet, $n$ property formed protessional opinion as to the length of tiune after delivery during which it is possible to introfluce the whole land into the uterus in a natural ease; and it is the whole hand that has to be introduced with a view to doing completely the operation I propose. 'The nearest approale to conditions sinilar to those of my case is found in instances of retention of the placenta. Active interferenee in this molbicl condition implies introduetion of fingers, and often of the whole liand; and the difliculty feared is contraction of the intermal os uteri or higher up.

\title{
The Septic Influence of Lochial Discharge.
}

In a treatise pnblished at Giessen, Prof. Kenren describes a series of experiments undertaken in order to ascertain the poisonous influence of normal and abnormal lochial fluids at diflerent periods after parturition. The lochial fluid was taken daily for fiom five to seven lays after delivery, and its effuct wis tried in two different ways; first, by injeetion under the skin of rabbits, and secondly by inoculation of the parturient women themselves. The author arrived at the

\footnotetext{
${ }^{2}$ System of Midwifery, Heath's translation, vol. ii. p. 25.
} 
following results: In all eases, even when the eourse of the puerperal state was periectly normal, the lochial tluil injected into rabbits produced extensive inflammation and suppuration in the eelhular tissue at and around the point of injection. In mally cases the lochial fluid, even of the first day, produced diffine phlegmonous inflummetion, in others this was only produced by the lochia of the sccond or third day. 'The intensity of the effect increased in proportion to the time which had elupsed since delivery, within the linit of the period of olservition; but it was not asecrtained precisely when the maximum was reached, or when the poisonous quality had disappeared. The author coneluded, however, that this would be the case when the disclurge hat become purcly mneous. The latcr lochia of healthy puerperal wonen produced abscesses similar to those eansed by putrid lochia in the earliest days. The contitutional distnrbance assoriated with the abscesses incressed in a similar matio, in proportion to the clate of the lochia. The diumal temperatere of the animals experimented upon showed a certain rescunblance to that of the puerperal wome'n in whon the lochine wre putritl. 'The blood which flowed from the genitals immediately" after delivery proved to be comparatively hurmless when injected subcutaneously. One execption, lowever, to this me ocemrel, a case in which a slongh was formed at the point of injection, and the cellular tissne leneath becamo infiltrated with pus. 'The author considcred, however, that this might have arisen from some want of care in filtering the blood or making the injection.

'The result of experiments hy inoculation upon the puerperal women themselves was that the lochial fluid of the first and second day produced scarcely any reaetion, only in some cases a slight appearanee of inflummation. That of the third and later days, however, producerl decided infammation, but only of a slight and linited chanuster, if taken from a liealthy purperal woman. The results of inoculation thus differed somewhat from those of sulsentaneous injections in rabbits, in which nomal lochia of the later days produced as acute an inflannation as putriel lochia. In cases where any puerperal disorder occurred, the inoculation produced a lighter degree of inflimmation, and this occurred, not enly with putrid lochial fluirl, but with that which, to the senses, dirl not apponr other than nornual, a fact which las great importance in reference to the ctiology and prophylaxis of pucrperal septiesenia. The first marked rise of temperature lid not coincide in time with the appearance of this poisonous quality in the discliarge, but in some enses oucurred earlicr, and in some later. - Obstetrical Journal of Great Britain, Nov. 1877, fion Archiv für Ciynälologie, B. xi. H. 2.

\section{Mammary Abseess treated Antiseptically.}

Dr. James Carmicinakir reports (Edinburgh Med. Journal, Oet. 1877) the following case where the antiseptic methol of treatment contrasted most fiwourably with the old:-

Mrs. B., multipara, of somewhat delicate constitution, fell in labour on the 15 th of Norcmber. I saw her about six hours after. On cxamination, the breceh presented at the outlet. During the interval between the pains, the feet were bronght down, and delivery was easily effected. All went on well till the third day, when the breasts became gorged, and she had au attack of epheneral fever, which passed off in a few hours in the usual way. The child took the breast lazily, and both nipples became sore. Glycerine of tannin was applied, and the child allowed to take the breast only through a shielded teat. The patient eontinned to reeover slowly, and was able to be up on the eleventh day. The nipples, however, were still troublesome, but otherwise she appeared well. On the fittenth day the right lreast was painful, and a hardness could be felt in the submamnary tissue fixing the breast to the pectoralis musele. The swelling 